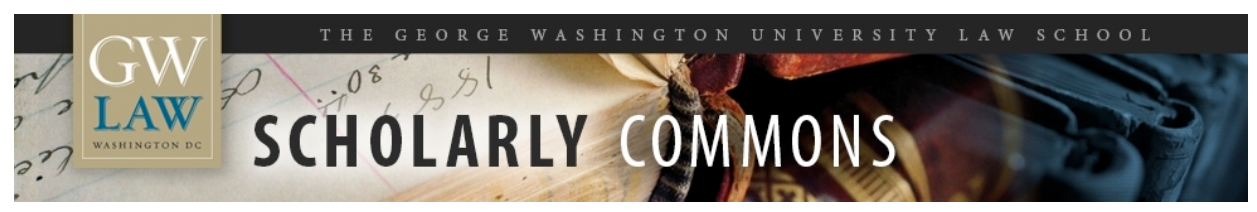

\title{
Constitutional Change and Responsibilities of Governance Pertaining to the Faith-Based and Community Initiative
}

Ira C. Lupu

George Washington University Law School

Robert W. Tuttle

George Washington University Law School

Follow this and additional works at: https://scholarship.law.gwu.edu/faculty_publications

Part of the Law Commons

\section{Recommended Citation}

Ira C. Lupu \& Robert W. Tuttle, Constitutional Change and Responsibilities of Governance Pertaining to the Faith-Based and Community Initiative at Conference on Innovations in Effective Compassion (June, 2008).

This Article is brought to you for free and open access by the Faculty Scholarship at Scholarly Commons. It has been accepted for inclusion in GW Law Faculty Publications \& Other Works by an authorized administrator of Scholarly Commons. For more information, please contact spagel@law.gwu.edu. 


\title{
CONSTITUTIONAL CHANGE AND RESPONSIBILITIES OF GOVERNANCE PERTAINING TO THE FAITH-BASED AND COMMUNITY INITIATIVE
}

\author{
Ira C. Lupu \\ Robert W. Tuttle
}

Thirty years ago, a governmental initiative designed to encourage the participation of houses of worship in government-financed social services would have been unthinkable. At that time, many faith-based social welfare providers received public funding, but those providers were generally large, highly secularized entities (Monsma, 1996; Saperstein, 2003). For years, prominent religious denominations had chosen to deliver social services through separately incorporated and specialized entities, such as Catholic Charities and Lutheran Social Services. This service delivery structure permitted social service professionals to carry out their functions without day-to-day oversight by religious leaders. The structure also insulated houses of worship from the responsibilities and potential liabilities associated with the delivery of social services.

As a constitutional matter, the First Amendment's Establishment Clause, which provides that "Congress shall make no law respecting the establishment of religion," stood as an impediment to government financing of houses of worship and other institutions that engaged in religious instruction. The Supreme Court had interpreted the Clause to prohibit government funds from flowing directly to "pervasively sectarian" entities (Hunt v. McNair, 1973), a category that encompassed houses of worship, religious elementary and secondary schools, and colleges with a strong religious identity.

Between 1988 and 2000, however, the relevant constitutional law shifted, and policies on public aid to faith-based service providers began to follow suit. In Bowen v. Kendrick (1988), the Supreme Court upheld legislation that explicitly allowed religious organizations to receive funding as service providers for a program aimed at adolescent sexuality. Following the Bowen decision, courts started to relax the constitutional restrictions governing expenditures to religious entities. Themes of equal access to public resources by religious actors began to emerge in the legal and political culture, as exemplified by the Charitable Choice provisions of the welfare reform legislation, the Personal Responsibility and Work Opportunity Reconciliation Act of 1996. These provisions include (1) a mandate on participating states to treat religious entities on the same basis as secular service providers, (2) a promise that participating religious organizations can retain their religious character and identity, (3) a requirement that all providers respect the religious liberty of beneficiaries, (4) a prohibition on direct government funding of 
"sectarian worship, instruction, or proselytization," and (5) an affirmation that participating religious organizations retain their right to make religion-based employment decisions.

When George W. Bush began his presidency, the legal ban on grants to pervasively sectarian entities had been effectively eliminated (Mitchell v. Helms, 2000). The Supreme Court's decision in the Cleveland school voucher case (Zelman v. Simmons-Harris, 2002), which upheld against constitutional challenge a program of voucher-based financial support for education in private schools (some with a strong religious identity), paved the way for greater latitude in the involvement of faith-based organizations in government-financed programs. Nevertheless, important constitutional restrictions on government support for religious activity remain in effect.

Immediately on taking office in January 2001, President Bush issued executive orders that set in motion the Faith-Based and Community Initiative (FBCI) (Exec. Orders 13,198-13,199). These orders created the White House Office of Faith-Based and Community Initiatives (WHOFBCI) and established centers for this initiative in the most prominent grant-making agencies in the federal government. The President ordered the agency centers to find and eliminate unnecessary obstacles to the participation of faith-based and community organizations in governmentfinanced social services. In 2003 and thereafter, these agencies promulgated a series of regulations designed to eliminate such impediments and ensure the equal treatment of religious organizations seeking to partner with federal or state agencies in the delivery of social services. For example, the U.S. Department of Health and Human Services (HHS) issued a regulation focused on the equal treatment of religious organizations that participate in the agency's funding programs, and many federal agencies have similar regulations (for additional examples, see the Table of Legal Materials in Appendix A).

From the beginning of this effort, however, the FBCI has faced the formidable task of translating a set of emerging constitutional principles into workable regulatory concepts. This initiative rests on a premise of neutrality or nondiscrimination between secular and religious providers; in other words, faith-based providers are equal to secular service providers in eligibility to participate in the delivery of government-financed services. But the relevant constitutional law still embodies remnants of a premise in tension with complete neutrality; namely, religious activities are constitutionally different from secular activities, even if both are undertaken for the same public purposes. The Establishment Clause of the First Amendment continues to impose constraints on public financing of religious activity, and many state constitutions have similar limitations. 
The existing literature on the legal parameters surrounding the FBCI has tended to take one of two forms. Much of the literature emphasizes the social, religious, cultural, political, and administrative milieus in which this initiative developed, and does not delve deeply into legal considerations (Monsma, 1996; Farris, Nathan, \& Wright, 2004; Ryden \& Polet, 2005; DiIulio, 2007). More traditional legal literature either defends the FBCI's basic premise of "the level playing field" (Esbeck, 1997) or is critical of the initiative for being insensitive to traditional concerns of church-state separation (Saperstein, 2003; Gilman, 2002, 2007a).

However, a more comprehensive approach to legal analysis of the FBCI focuses on the rate and direction of legal change in the relevant constitutional norms, the details of the implementation to the Initiative and the constitutional constraints that surround the FBCI, and the litigation associated with this Initiative (Lupu \& Tuttle, 2002, 2003, 2004, 2005a, 2005b, 2006, 2007). This paper addresses the regulatory response of various government agencies to the relationship between the FBCI's agenda and the changing legal environment. After briefly mapping the key developmental points in the relevant constitutional law, the discussion focuses on the particulars of regulatory language as put into place by the agencies of the U.S. government and considers the litigation efforts that have occurred in conjunction with this initiative. Some of the litigation may be traced, at least in part, to inadequacies in the FBCI's regulatory reform. In addition, the paper provides recommendations for federal and state regulatory language that could be used to facilitate the FBCI while keeping it within constitutional bounds. The paper does not systematically evaluate the less formal documents and processes on which the federal government frequently relies to guide grant recipients.

\section{THE EVOLVING CONSTITUTIONAL ENVIRONMENT}

The regulatory reforms and the litigation challenges prompted by the FBCI can best be understood in light of the evolving principles of First Amendment law. For over six decades, the Supreme Court has consistently interpreted the Establishment Clause of the First Amendment to impose some constraints on public financing of religious entities (Everson v. Board of Ewing Township, 1947). Although the interpretive details have changed, the Court's guiding principle throughout has been that the government may not promote or directly subsidize religious worship or instruction in a particular faith. When the government engages in or directly supports religious indoctrination, it violates the core understanding of the First Amendment ban on "establishment of religion." This prohibition, called the "no-indoctrination" principle, is absolute. Unlike other values protected by the First Amendment, the ban on religious establishment is never balanced against the social benefits that would arise from a violation of the principle. Many state constitutions have similar limitations (Lupu \& Tuttle, 2002). 
From the early 1970s until the late 1990s, the Supreme Court implemented that principle with a sharply defined rule that government could not make direct grants to "pervasively sectarian" entities, such as houses of worship, religious schools, and even social welfare organizations that had an overtly religious character. The Court reasoned that grants to such organizations would inevitably support the mission of religious indoctrination because the government was incapable of ensuring that the organization would use public funds solely for secular activities.

Between 1981 and 2002, however, three new and highly relevant constitutional principles emerged. The first principle involves the Court's gradual abandonment of the overly broad rule that pervasively sectarian entities may not participate in social welfare programs and replacement of that rule with a narrower no-indoctrination rule that the government may not directly finance religious activities (Agostini v. Felton, 1997; Mitchell v. Helms, 2000). At the heart of this shift is the Court's determination that faith-based entities will not inevitably divert public resources to serve their religious mission, but instead may be trusted to comply with restrictions on how public aid may be used. Such trust is conditional; the Court ruled in Mitchell that aid to religious entities must incorporate adequate safeguards, including monitoring, against the diversion of public funds to religious use.

The second principle concerns "beneficiary choice." When the funding program is structured to permit beneficiaries a genuine and independent choice among secular and religious providers, and public funds are directed to the provider only as a result of such choices by beneficiaries, religious organizations may use these funds for religious indoctrination as an element of the relevant service (Zelman v. Simmons-Harris, 2002). For example, school voucher programs may permit participating schools to include prayer or religious instruction as an element of the education of voucher students, so long as students and their families have a genuine choice among religious and secular schools and schools only receive funds as a result of the exercise of such a choice. This financing structure is typically labeled indirect funding because of the role of the beneficiary as an intermediary in distribution of public funds to religious entities. Programs that fall under the principle of beneficiary choice thus are outside the scope of the noindoctrination principle because the beneficiary, rather than the government, is responsible for any religious indoctrination that occurs within the funded program.

The third principle involves contexts in which the government is providing a forum for speech rather than grants for the performance of services; in such situations the Court began to recognize claims of nondiscrimination, or equal access, by religious persons or causes (Widmar v. Vincent, 1981; Lamb’s Chapel v. Center Moriches Union Free School Dist., 1993; Rosenberger v. Univ. of Virginia, 1995; Good News Club v. Milford Central School, 2001). 
Supporters of the FBCI embrace this principle of equal access and argue that it should be extended to public grants and other forms of financial support. In Locke v. Davey (2004), however, the Court ruled that, even in a beneficiary choice program, states have broad discretion in choosing whether or not to provide financial support for religious activity. Thus, in programs involving public expenditures for services, a policy of equal access is constitutionally permissible, but not constitutionally mandatory.

Unless the three principles are understood in a textured and interactive way, there are deep and ineradicable tensions among them. An unmodified principle of equal access seems at first glance to fully support the premise, central to the FBCI, that government grant programs should provide a level playing field for competition among religious and secular service providers. Moreover, an unadorned principle of beneficiary choice appears to suggest that the government may support social service with religious content to beneficiaries who voluntarily select that kind of service, so long as the government provides an adequate range of religious and secular options to beneficiaries.

The no-indoctrination principle, however, constrains the scope of the equal access principle by prohibiting the government from directly financing programs that include explicitly religious content. Moreover, the no-indoctrination principle is not limited to cases of involuntary or coercive religious experience. Because the government may not directly pay to indoctrinate even those who freely seek such an experience, beneficiary choice programs must involve beneficiary control over the direction of funds as well as genuine choice among secular and religious service providers.

Constitutionally appropriate administration of the FBCI thus depends in significant ways on (1) a nuanced appreciation of the three principles, (2) identification of areas of reconciliation among them, and (3) careful guidance to both government grantors and potential grantees about these cross-cutting constitutional parameters.

\section{REGULATORY REFORM AND THE IMPERFECT MESH WITH CONSTITUTIONAL CHANGE}

Among the very first official acts of President Bush were his two executive orders, issued January 29, 2001, designed to create an active administrative presence for the FBCI. These orders created WHOFBCI (E.O. 13,199) and the FBCI centers within each of the six major grant-making agencies of the federal government (E.O. 13,198). Both orders emphasized the principle of equal access by affirming the concepts of a level playing field and evenhandedness 
among religious and secular organizations. Neither order explicitly referenced the constraint imposed by the no-indoctrination principle or the opportunities created by the beneficiary choice principle. One of the chief purposes of both orders was the elimination of "unnecessary legislative, regulatory, and other bureaucratic barriers that impede effective faith-based and other community efforts to solve social problems."

In 2001-2002, the main sticking point in the congressional deliberations on legislation related to the FBCI was the issue of religious selectivity in hiring by publicly supported religious entities (Farris, Nathan, \& Wright, 2004). Many supporters of the FBCI wanted to reaffirm that such organizations would retain their current exemption, codified in Title VII of the 1964 Civil Rights Act, from the prohibition on religious discrimination in employment. Others, including some who supported most of the FBCI principles, believed that faith-based entities should not be able to limit publicly financed jobs to members of their own faith. Still others feared that the FBCI would lead to violations of the no-indoctrination principle or that the mission of religious entities would be compromised if they accepted public funds.

On December 12, 2002, the President acted unilaterally with an executive order entitled "Equal Protection of the Laws for Faith-Based and Community Organizations." This order made the key principles of the FBCI applicable to all federal programs of social welfare funding.

In 2003-2004, through the coordination of WHOFBCI and the FBCI agency centers, all of the major granting agencies promulgated a set of regulations designed to guide the participation of faith-based organizations in the grant-making process. These regulatory reforms (see the Table of Legal Materials in Appendix A) have achieved three substantial successes. First, the regulations have clarified that houses of worship and other entities with a strong religious identity are eligible to receive public grants as social welfare service providers. Prior to the Supreme Court's decision in Mitchell v. Helms (2000), which effectively eliminated the exclusion of pervasively sectarian entities from direct government funding, the eligibility of such organizations had been in doubt. These sets of regulations specify that participating organizations have a right to retain their religious character, including the display of religious icons, the selection of a governing board on a religious basis, and the inclusion of religious references in their mission statements.

Second, the regulations provide that service beneficiaries have the right to be free from religious coercion or discrimination in federally financed activity. No prior U.S. statute or regulation prohibited federal grantees from engaging in discrimination against beneficiaries based on religious identity or on the beneficiaries' willingness to participate in religious activity. This is a 
very important development, although respect for these rights could be enhanced through an affirmative obligation of faith-based grantees to inform beneficiaries of the protections. HHS regulations for substance abuse treatment services provide an example of such a notice.

Third, the regulations address the responsibility of all grantees with respect to the use of government funds to support religious activities. Nearly all federal agencies involved in the FBCI now have in place a regulation prohibiting the direct financing of "inherently religious activities, such as religious worship, instruction, or proselytization." Grantees may engage in such activities only with private funds, and must separate those activities in time or place from activities directly funded by the government. These content restrictions have been reinforced by a variety of guidance documents and training materials developed by the WHOFBCI and federal agencies.

The emphasis on the concept of "inherently religious activities," however, may have produced an ambiguity in the regulatory environment. The concept of inherently religious activities is derived from Bowen v. Kendrick (1988) where the Court ruled that services related to adolescent sexuality were not "inherently religious" because such services could be performed with exclusively secular content. Thus, the FBCI's ban on direct funding for inherently religious activities is accurate to a point because the no-indoctrination principle bars public support for worship, religious instruction, and proselytizing. But the regulations do not confront the question of whether social services that have explicitly religious content are precluded by the regulation. If understood too narrowly, the regulatory proscription on direct government financing of religious instruction significantly understates the no-indoctrination principle, which bars direct government financing of any activity with "specifically religious content" (Bowen v. Kendrick, 1988).

We believe the existing regulatory formula creates ambiguity with respect to direct funding of social services that have religious content. Some social services may be delivered using religious content, even if such content is not a necessary part of the service. For example, a grantee may teach the skills and behaviors necessary for success in the workplace, the value of marriage, the benefits of sexual abstinence outside of marriage, or the benefits of a drug-free lifestyle. The provision of these services may be in entirely secular terms or in terms that include explicitly religious language and beliefs. While it is possible that federal officials might provide sufficient warning and guidance, the regulations themselves do not warn grantors and grantees that the inclusion of specifically religious content in the delivery of such services may put the granting agency in conflict with the no-indoctrination principle and expose both the public grantor and the private grantee to legal consequences. 
At times, federal agencies have provided appropriate explanation that the prohibition on direct funding of "religious instruction" includes social service materials that contain religious content. For example, earlier this year, the Administration for Children and Families (ACF) issued a memorandum to grantees under the Healthy Marriage Initiative. The memorandum explained that curricular materials must be "neutral with respect to religion," and provided examples of curricula that would not qualify for direct government support because the materials included religious content. Another example of appropriate guidance can be found in the recent memorandum - issued by ACF in the wake of the settlement in ACLU of Massachusetts v. Leavitt - on the proper and improper ways to spend grant funds for programs that promote sexual abstinence by minors.

An additional, though related, ambiguity may arise from the regulatory guarantee that faith-based organizations may receive grants and still retain their religious character. Even though the regulations define "religious character" in terms associated with organizational identity (acceptability of religious board members, maintenance of religious content in mission statement, etc), it is possible that organizations may misinterpret the guarantee as a representation that religious content in their government-financed services is acceptable if such content reflects the entity's religious character.

The ambiguity of the regulatory focus on "inherently religious activities" is especially problematic when applied to the direct funding of social services that aim at personal transformation. If faith-based social service agencies deliver food, shelter, or other material goods, it is usually not difficult for them to segregate those goods from religious activity and to ensure that government funds do not pay for the latter. In such a context, government funds can be used exclusively to support secular goods and services, and religious activity can be offered, as the federal regulations uniformly require, at a "separate time or place" not subsidized by government funds. In contrast, transformative services, such as those aimed at substance abuse, sexual abstinence among unmarried minors, and rehabilitation of those incarcerated for crime, may be much harder to segregate into secular and religious components. Most of the successful litigation (discussed below) against government-financed faith-based services has arisen in the context of transformative services.

Uncertainty about the constitutionally acceptable use of direct grants also presents a difficult problem in the context of grants designed to build the capacity of faith-based organizations to provide social services. Such grants have been a central building block of the FBCI through the Compassion Capital Fund (CCF). Depending on the activities funded by the capacity-building grants, it can be difficult to segregate secular and religious activities. If a recipient of such grants 
provides both religious and secular services, aid for building the organization's capacitythrough computer technology, for example - is likely to benefit the organization's religious programs as well as its secular programs, thus making the aid vulnerable to constitutional challenge. The one decided case on the subject upheld a capacity-building grant to a marriagestrengthening program, but did so only in light of a specific finding that the grantee had removed the religious content from all the activities that benefited from federal support for the grantee's capacity. (Christianson v. Leavitt, 2007). Thus, the public funding for capacity-building supported exclusively secular services.

Moreover, $\mathrm{CCF}$ grants often involve private intermediaries empowered by the government to make subgrants. The Supreme Court has ruled that, like the government, these subgrantors are prohibited from directly subsidizing religious indoctrination (Bowen v. Kendrick, 1988). In the early years of the FBCI, the federal agencies may not have been sufficiently sensitive to the problems of necessary guidance for either intermediaries or subgrantees. The concern remains that the federal regulations have generally repeated the formula by which direct grants may not be used for inherently religious activities.

An additional concern related to the current regulations is the existing legal requirement that the government monitor the content of government-financed social services provided by faith-based entities. The Supreme Court has ruled that such monitoring, which should not and need not be intrusive, is necessary to ensure compliance with the no-indoctrination principle; that is, to protect against unlawful diversion of public money to religious activity (Mitchell v. Helms, 2000; Agostini v. Felton, 1997). While the grantees are subject to the same federal or state monitoring imposed on any grantee, the current $\mathrm{FBCI}$ regulations prohibit the imposition of any requirement that faith-based organizations be treated differently than secular organizations for purposes of regulatory compliance. Although the emphasis on equal treatment is salutary, the regulations may not adequately highlight the government's continuing constitutional obligation to provide particularized monitoring that focuses on the risk of diversion of public funds to religious activities. In a 2006 study of programs that provide funding for faith-based and community organizations, the Government Accountability Office found that federal agencies gave auditors little guidance in assessing whether grantees complied with restrictions on use of direct funds for religious activities (GAO, 2006).

Even with respect to indirect funding, where constitutional restrictions are looser and room for inclusion of religious content correspondingly greater, federal programs could provide better regulatory language for government officials and faith-based grantees. Apart from regulations implementing statutory Charitable Choice provisions, regulations promulgated by the federal 
agencies do not define indirect funding. Instead, the agency-wide FBCI regulations proscribe certain religious content in situations of direct funding and indicate that such a proscription does not apply to a program of indirect funding.

Although this omission has not appeared to cause the same degree of uncertainty as the proscription on direct financing of inherently religious activities, potential grantors and grantees could benefit from specific regulations with respect to indirect funding. (Some agencies have developed detailed resources that provide clarity about the constitutional parameters of indirect funding. See for example the Department of Labor (2005) resource "Partnering with Integrity.")

The phrase "indirect funding" is drawn from the Cleveland school voucher decision (Zelman $v$. Simmons-Harris, 2002) and other Supreme Court cases involving policies that empower individual beneficiaries to select a religious entity as the provider of publicly supported services (Zobrest v. Catalina Foothills Sch. Dist., 1993; Witters v. Wash. Dept. of Services for the Blind, 1986). The Court's decisions upholding such programs emphasized the ability of beneficiaries to make a "genuine and independent choice" among secular and religious alternatives. Thus far, the agency-wide FBCI regulations for implementing programs of beneficiary choice have only indicated that the programs must offer beneficiaries a choice to which the beneficiaries do not have religious objections. Those regulations have not taken the constitutionally mandated next step of requiring that voucher programs offer a religiously neutral menu of service providers, including a secular alternative.

Moreover, federal regulations have not yet made clear the requirement that indirect aid must in some fashion pass through the control of the beneficiary, though not necessarily by the mechanism of vouchers or other tangible instruments (Freedom from Religion Foundation, Inc. v. McCallum, 2003). In other words, the concept of beneficiary choice means more than the simple fact of voluntary selection by beneficiaries among a number of providers. The regulations should state that the beneficiary must be empowered to designate the provider as a recipient of government funds and to stop the flow of those funds by withdrawing from that provider.

In addition, the regulations might fruitfully sharpen the concept of beneficiary choice by greater attention to particular service contexts. What may constitute an adequate mechanism for choice when parents choose elementary or secondary schools (Zelman v. Simmons-Harris, 2002) may be insufficient when the relevant service involves people suffering from drug addiction, with accompanying impairment of cognitive capacity, or institutionalized foster care of minor children arranged by state officials (Teen Ranch, Inc. v. Udow, 2007). In cases of the latter type, 
involving state officials rather than parents acting on behalf of minors, it may be that no one is competent to exercise beneficiary choice in favor of religious programming.

Finally, despite substantial efforts to involve the states in the efforts associated with the FBCI, the regulatory analysis and communication of various legal doctrines of federalism could be improved for this initiative. For example, federal agencies have at times confusingly explained the relationship between federal law and state law, especially with respect to the highly controversial issue of religious selectivity in hiring by faith-based organizations. An exemption from federal restrictions on faith-based hiring does not automatically create an exemption for federal grantees from state law restrictions on faith-based hiring decisions.

Moreover, the states themselves - even those with their own active faith-based and community initiatives - generally have not taken on the necessary task of supplying state-level regulatory content to granting agencies and potential grantees. To be successful at the state and local levels, the FBCI needs to include a legal and bureaucratic program designed to institutionalize its premises. Whether the cause is legal uncertainty or bureaucratic inertia, the states, which are the locus of most grant-making activity, have made virtually no progress in developing their own regulatory frameworks, even with respect to specific questions raised by state constitutional law. In some states, these state constitutional questions are substantial and include limits on the use of even indirect public aid for religious activity (Lupu \& Tuttle, 2002).

\section{THE LITIGATION SURGE PRODUCED BY THE FBCI}

Concerns about regulatory precision and transparency are not merely academic. Since the inception of the FBCI, government funding of faith-based social services has generated a significant volume of litigation and there has been a considerable increase in the number of lawsuits and judicial decisions about publicly financed, faith-based social services in the past 6 years. Most of these lawsuits have been initiated by public interest groups that are committed to strong principles of church-state separation (see the Table of FBCI-Related Litigation in Appendix B). Freedom from Religion Foundation, Inc. (FFRF) has been the most active instigator of this sort of litigation. Americans United for Separation of Church and State, the American Civil Liberties Union, the American Jewish Congress, and other groups have played a similar role.

The Table of FBCI-Related Litigation lists all of the cases brought so far, categorized by outcome: Victories for Challengers to Government Action (7), Victories for Defenders of 
Government Action (9), Settlements and other Terminations Before Decision (7), and Lawsuits Still Pending (2). These cases involve a wide variety of social services, including treatment for substance abuse, sexual abstinence for unmarried minors, work training, prisoner rehabilitation, mentoring the children of prisoners, education in pastoral care for nurses, custodial foster care for troubled teenagers, chaplaincies for public employees and patients in public hospitals, and the provision of shelter for the homeless. In a few of these cases early in the FBCI, the evidence suggested that the grantee had received inadequate guidance, which led to settlements in favor of the challengers or judicial rulings against the government (see, for example, FFRF v. Montana Office of Rural Health, 2004; ACLU of Massachusetts v. Leavitt, 2006).

An elaborate body of law has now developed on the subject of partnerships between government and faith-based organizations in the delivery of social services, although few lawyers are aware of this as a defined field. Most of the victories and favorable settlements for the challengers to government action and several of the government victories as well (Teen Ranch v. Udow, 2007; Christianson v. Leavitt, 2007) have involved a strong invocation of the no-indoctrination principle. If grantees use direct government support to finance the interweaving of religious themes with social services, they invite successful lawsuits against the grantor and themselves. All lower court decisions have upheld the importance of this prohibition on government-financed indoctrination. In sharp contrast, the government has typically prevailed in suits asserting other kinds of claims, such as unsuccessful allegations of unlawful preference for religious over secular entities (FFRF v. Towey, 2005), unlawful religious discrimination in hiring (Lown v. Salvation Army, 2005), or improper structures of indirect financing (FFRF v. McCallum, 2003; American Jewish Congress v. Corporation for National and Community Service, 2005).

In June 2007, the Supreme Court decided an important case that challenged the general policies of the FBCI rather than specific grants made under it. In Hein v. Freedom from Religion Foundation, Inc., the Court ruled that federal taxpayers lacked standing to complain about the constitutionality of discretionary expenditures made by federal executive agencies to promote the FBCI. The Hein ruling rests on a distinction between legislative decisions to make expenditures explicitly in support of religious causes or entities and discretionary executive decisions to spend in service of these same ends. Taxpayers may now challenge in the federal courts only spending decisions that have been explicitly authorized by legislatures. The Hein decision may well slow the pace of challenges to particular grants under the FBCI because some of these grants are not made pursuant to explicit legislative authority; however, Hein will not eliminate such challenges (Lupu \& Tuttle, 2008). 


\section{IMPLICATIONS}

The FBCI resides in a constitutional and regulatory milieu that requires detailed regulations and careful guidance to be provided to grantors and grantees. Federal agencies have made some progress in this regard, but more needs to be done. This analysis leads to a number of recommendations that may facilitate a more administratively successful integration of the $\mathrm{FBCI}$ with the present contours of the relevant law:

1. The regulations should be revised to clarify the full scope of the prohibition on direct funding of activity that has explicitly religious content. Such clarification will be most useful if it specifically identifies situations, such as faith-intensive treatment programs for substance abuse, in which grantees are likely to run afoul of the noindoctrination principle.

2. Federal agencies should expand their regulatory concern to indirect financing, with particular attention to the adequacy of secular alternatives and the precise mechanisms of beneficiary choice.

3. Federal agencies should provide greater clarity about the relationship between federal and state law, especially regarding the preemptive (or nonpreemptive) effect of exemption from federal policies of nondiscrimination in employment.

4. Federal agencies should impose a constitutionally sensitive system of monitoring to ensure that grantees do not divert funds to religious activities.

5. Federal agencies should continue to provide improved guidance for private intermediaries, especially with respect to capacity-building grants.

6. Federal agencies should continue to make the protections for beneficiaries more robust, by requiring providers to inform beneficiaries that they have the right not to participate in religious activities and that their right to receive services does not depend on such participation.

7. States and localities should continue to undertake efforts to educate grant officers and grantees, actual and prospective, concerning the relevant restrictions under both state and federal constitutional law.

If these recommendations are implemented, it is likely that fewer lawsuits will be filed challenging grants to faith-based organizations, more grantors and grantees will be willing to participate actively in the FBCI, and the rights of beneficiaries will be fully protected. Under such conditions, the attractive promise of a level playing field for religious and secular organizations, and the rich involvement of both, can be realized in ways that are consistent with constitutional norms and traditions. 


\section{ACKNOWLEDGMENTS}

The authors thank David Wright of the Roundtable for his very helpful comments on an earlier draft of this paper.

\section{APPENDIX A:}

\section{TABLE OF LEGAL MATERIALS}

\section{Legislative and Regulatory Materials}

Personal Responsibility and Work Opportunity Act of 1996, Pub. L.. No. 104-193, 110 Stat. 2105 (codified as amended in various sections of 42 U.S.C., including 42 U.S.C. sec. $604 \mathrm{a}$ et seq. (1996)

Exec. Order 13,198, 3 C.F.R. 750 (2002)

Exec. Order 13,199, 3 C.F.R. 752 (2002)

Exec. Order 13,279, 3 C.F.R. 258 (2003)

U.S. Department of Agriculture, Equal Opportunity for Religious Organizations, 7 C.F.R. Part $16(2004)$

U.S. Department of Education, Participation in Education Department Programs by Religious Organizations; Providing for Equal Treatment of all Education Program Participants, 34 C.F. R. Parts 74, 75, 76, and 80 (2004)

U.S. Department of Health \& Human Services, Participation in Department of Health \& Human Services Programs by Religious Organizations; Providing for Equal Treatment of all Department of Health \& Human Services Program Participants, 45 C.F.R. Parts 74, 87, 92, and 96 (2004)

U.S. Department of Housing and Urban Development, Equal Participation of Treatment for Faith-Based Organizations, 24 C.F.R. Parts 5 and 570 (2004)

U.S. Agency for International Development, Participation by Religious Organizations in U.S. AID Programs, 22 C.F.R. Parts 202, 205, 211, and 226 (2004)

U.S. Department of Justice, Equal Treatment for Faith-Based Organizations, 28 C.F.R. 38.138.2 (2004)

U.S. Department of Labor, Equal Treatment in Department of Labor Programs for Religious Organizations; Protection of Religious Liberty pf Department of Labor Social Service Providers and Beneficiaries, 29 C.F.R.2.2.32 (2004)

U.S. Department of Veterans Affairs, VA Homeless Providers Grant and Per Diem Program; Religious Organizations, 38 C.F.R. Part 61 (2004) 


\section{Selected Administrative Resources}

Government Accountability Office, Faith-Based and Community Initiative: Improvements in Monitoring Grantees and Measuring Performance Could Enhance Accountability (2006)

U.S. Department of Health \& Human Services, Administration for Children \& Families, Office of Family Assistance, "Curricular Use and Compliance with 45 CFR Part 87” (January 23, 2008)

U.S. Department of Labor, Employment and Training Administration, "Training and Employment Guidance Letter 1-05” (July 6, 2005)

White House Office of Faith-Based and Community Initiatives, Guidance to Faith-Based and Community Organizations on Partnering with the Federal Government (2006)

White House Office of Faith-Based and Community Initiatives, Promoting Equal Treatment: A Guide for State \& Local Compliance with Federal Regulations (2006)

\section{Decided Cases}

Bowen v. Kendrick, 487 U.S. 589 (1988)

Everson v. Bd. of Educ., 330 U.S. 1 (1947)

Flast v. Cohen, 392 U.S. 83 (1968)

Freedom from Religion Foundation, Inc. v. McCallum, 324 F. 3d 880 (7th Cir. 2003)

Good News Club v. Milford Central School, 533 U.S. 98 (2001)

Hein v. Freedom from Religion Foundation, Inc., 127 S. Ct. 2553 (2007)

Hunt v. McNair, 413 U.S. 734 (1973)

Lamb’s Chapel v. Center Moriches Union Free School Dist., 508 U.S. 384 (1993)

Lemon v. Kurtzman, 403 U.S. 602 (1971)

Locke v. Davey, 540 U.S. 712 (2004)

Mitchell v. Helms, 530 U.S. 793 (2000)

Rosenberger v. Rector \& Visitors of the Univ. of Virginia, 515 U.S. 819 (1995)

Widmar v. Vincent, 454 U.S. 263 (1981)

Witters v. Wash. Dept. of Services for the Blind, 474 U.S. 481 (1986)

Zelman v. Simmons-Harris, 536 U.S. 639 (2002)

Zobrest v. Catalina Foothills Sch. Dist., 509 U.S. 1 (1993) 


\section{APPENDIX B: \\ TABLE OF FBCI-RELATED LITIGATION}

Victories for Challengers to Government Action

Americans United for Separation of Church \& State v. Prison Fellowship Ministries, 509 F.3d 406, U.S. Court of Appeals for the 8th Circuit, 2007 (affirming the invalidation of faith-based prison program, though reversing an order that Prison Fellowship Ministries repay the State of Iowa for unconstitutional programming)

American Civil Liberties Union Foundation v. Blanco, 2007 U.S. Dist. Lexis 74590, U.S. District Court for the Eastern District of Louisiana, 2007 (invalidating earmarked grants, without specified purposes or safeguards against diversion to religious activities, to named houses of worship)

Community House, Inc. v. City of Boise, 463 F.3d 1118, U.S. Court of Appeals for the 9th Cir. 2006 (affirming decision invalidating below-market lease from city to operator of homeless shelter because operator was engaged in religious indoctrination and sex discrimination)

Bush v. Holmes, 919 S. 2d 392, Supreme Court of Florida, 2006 (invalidating, on state constitutional grounds, a voucher scheme for sending children to private schools, religious and secular)

Freedom from Religion Foundation, Inc. v. Towey, 2005 U.S. Dist. Lexis 39444, U.S. District Court for the Western District of Wisconsin, 2005 (invalidating HHS grant to MentorKids USA because of religious content in the services provided)

Freedom from Religion Foundation, Inc. v. Montana Office of Rural Health, 2004 U.S. Dist. Lexis 29139, U.S. District Court for the District of Montana, 2004 (invalidating grants for the support of education in the practice of religion-based parish nursing)

Freedom from Religion Foundation, Inc. v. McCallum \& Faith Works Milwaukee, 179 F. Supp.2d 950, U.S. District Court for the Western District of Wisconsin, 2002 (invalidating grant for the direct support of faith-based residential service for the treatment of substance-addicted welfare recipients)

\section{Victories for Defenders of Government Action}

Hein v. Freedom from Religion Foundation, Inc., 127 S. Ct. 2553 (2007) (dismissing taxpayer challenge to executive expenditures promoting the FBCI)

Teen Ranch, Inc. v. Udow, 479 F.3d 403, U.S. Court of Appeals for the 6th Circuit, 2007 (affirming a decision upholding the exclusion from state assistance of faith-based residential service facility for teens with problems of substance abuse)

Christianson v. Leavitt, 482 F. Supp. 2d 1237, Secretary of Health \& Human Services, U.S. District Court for the Western District of Washington, 2007 (dismissing suit against capacity- 
building grant by HHS to faith-based marriage support group, on the grounds that the grant supported only secular activity)

Freedom from Religion Foundation, Inc. v. Nicholson, Secretary of the Department of Veterans' Administration, 469 F. Supp. 2d 609, U.S. District Court for the Western District of Wisconsin, 2007 (dismissing suit against hospital chaplaincy program of the Department of Veterans' Administration)

Freedom from Religion Foundation, Inc. v. Towey, 2005 U.S. Dist. Lexis 39444, U.S. District Court for the Western District of Wisconsin, 2005 (upholding, against claim of religious discrimination, subgrants from Emory University to faith-based health providers)

Lown v. Salvation Army, Inc., \& Commissioner, New York City Administration for Children's Services, 393 F. Supp. 2d 223, U.S. District Court for the Southern District of New York, 2005 (dismissing claim that religious selectivity in employment, by publicly supported Salvation Army, violated federal or state law)

American Jewish Congress v. Corporation for National and Community Service, 399 F.3d 351, U.S. Court of Appeals for the District of Columbia Cir., 2005 (rejecting constitutional challenge to system of indirect public financing for training of teachers placed at religious schools in AmeriCorps program)

Freedom from Religion Foundation, Inc. v. McCallum, 324 F.3d 880, U.S. Court of Appeals for the 7th Cir. 2003 (rejecting constitutional challenge to indirect payment for placement of drug offenders at faith-based residential treatment center for substance abuse)

American Jewish Congress v. Bost, U.S. District Court for the Southern District of Texas, 2002 (refusing to order restitution of public funds by operator of faith-based jobs program that had unlawfully used public monies for support of religious activity)

\section{Settlements and other Terminations Before Decision}

Freedom from Religion Foundation, Inc. v. Mitchell Roob, U.S. District Court for the Southern District of Indiana, 2007 (withdrawal of suit after state terminated the employment of a chaplain hired to minister to employees of state social service department)

Geneva College v. Chao, Secretary of Labor, U.S. District Court for the Western District of Pennsylvania, 2007 (suit alleging unlawful interference with college's religious autonomy in hiring settled after state and federal authorities withdrew objection to college's use of publicly supported employment search Web site)

Freedom from Religion Foundation, Inc. v. Alberto Gonzales, U.S. District Court for the Western District of Wisconsin, 2006 (withdrawal of suit after U.S. Department of Justice suspended its request for proposals to provide faith-based programming in federal prisons)

American Civil Liberties Union of Massachusetts v. Leavitt, Secretary of Health \& Human Services, U.S. District Court for the Eastern District of Massachusetts, 2006 (settlement of suit 
against HHS for grant to "Silver Ring Thing," a faith-based program promoting sexual abstinence among unmarried teens)

Freedom from Religion Foundation, Inc. v. Minnesota Faith/Health Consortium, Alberto Gonzales, U.S. District Court for the District of Minnesota, 2005 (withdrawal of suit after University of Minnesota altered curriculum in its program on the relationship between faith and health)

Bellmore v. Georgia Department of Human Resources \& United Methodist Children's Home, Georgia Superior Court, 2004 (settlement of employment discrimination suit in light of revision of state policy on religious discrimination in employment by state-supported faith-based organizations)

American Civil Liberties Union of Louisiana v. Foster, 2002 U.S. Dist. Lexis 13778, U.S. District Court for the Eastern District of Louisiana, 2002 (preliminary injunction, followed by settlement of suit against Governor of Louisiana with respect to program of state support for faith-based programs promoting sexual abstinence among unmarried teens)

\section{Lawsuits Still Pending}

Freedom from Religion Foundation, Inc. v. Bjergaard \& Dakota Boys and Girls Ranch, U.S. District Court for the District of North Dakota, 2007 (suit alleging unlawful state support for religion in faith-based group foster home)

Laskowski v. University of Notre Dame \& Spellings, U.S. Secretary of Education, U.S. Court of Appeals for the 7th Circuit, appeal pending, 2008 (suit alleging unlawful subgrants of public monies by University of Notre Dame to religiously affiliated colleges in federal program of teacher training)

\section{REFERENCES}

DiIulio, J. J., Jr. (2007) A centrist blueprint for America's faith-based future. Wildavsky Forum 2007.

Esbeck, C.H. (1997). A constitutional case for governmental cooperation with faith-based social service providers. 46 Emory L. J. 1.

Farris, A., Nathan, R., \& Wright, D. (2004, December). The expanding administrative presidency: George W. Bush and the Faith-Based Initiative. The Roundtable on Religion and Social Welfare Policy, Nelson A. Rockefeller Institute of Government, SUNY.

Formicola, J. R., Segers, M. C., \& Weber, P. (2003). Faith-based initiatives and the Bush administration: The good, the bad, and the ugly. Lanham, MD: Rowman \& Littlefield.

Gilman, M.E. (2002) Charitable Choice and the accountability challenge: Reconciling the need for regulation with the First Amendment's religion clauses. 55 Vanderbilt L. Rev. 797. 
Gilman, M. E. (2007) Fighting poverty with faith: Reflections on ten years of Charitable Choice. 10 Journal of Gender, Race, \& Justice 395.

Gilman, M. E. (2007). If at first you don't succeed, sign an executive order: President Bush and the expansion of Charitable Choice. 15 William \& Mary Bill of Rights J. 1103.

Lupu, I. C., \& Tuttle, R. W. (2002, December). Government partnerships with faith-based service providers: The state of the law. The Roundtable on Religion and Social Welfare Policy, Nelson A. Rockefeller Institute of Government, SUNY.

Lupu, I. C., \& Tuttle, R. W. (2003, December). Partnerships between government and faithbased providers: Annual report on the state of the law, fall, 2003. The Roundtable on Religion and Social Welfare Policy, Nelson A. Rockefeller Institute of Government, SUNY.

Lupu, I. C., \& Tuttle, R. W. (2004, December). The state of the law, 2004: Partnerships between government and faith-based organizations. The Roundtable on Religion and Social Welfare Policy, Nelson A. Rockefeller Institute of Government, SUNY.

Lupu, I. C., \& Tuttle, R. W. (2005). The faith-based initiative and the constitution. 55 DePaul L. Rev. 1.

Lupu, I. C., \& Tuttle, R. W. (2005, December). The state of the law, 2005: Legal developments affecting partnerships between government and faith-based organizations. The Roundtable on Religion and Social Welfare Policy, Nelson A. Rockefeller Institute of Government, SUNY.

Lupu, I. C., \& Tuttle, R. W. (2006, December). The state of the law, 2006: Legal developments affecting government partnerships with faith-based organizations. The Roundtable on Religion and Social Welfare Policy, Nelson A. Rockefeller Institute of Government, SUNY.

Lupu, I. C., \& Tuttle, R. W. (2007, December). The state of the law, 2007: Legal developments affecting government partnerships with faith-based organizations. The Roundtable on Religion and Social Welfare Policy, Nelson A. Rockefeller Institute of Government, SUNY.

Lupu, I. C., \& Tuttle, R. W. (in press). Ball on a needle: Hein v Freedom of Religion Foundation, Inc. and the future of establishment clause adjudication. B.Y.U. L. Rev.

Monsma, S. V. (1996). When sacred and secular mix: Religious nonprofit organizations and public money. Lanham, MD: Rowman \& Littlefield.

Ryden, D. K., \& Polet, J. (2005). Sanctioning religion? Politics, law, and faith-based public services. Boulder, CO: Lynne Rienner.

Saperstein, D. (2003). Public accountability and faith-based organizations. 116 Harv. L. Rev. 1353. 
U.S. Department of Labor, Center for Faith-Based and Community Initiatives. (2005, July 27). Partnering with integrity — what faith-based organizations, community groups, and workforce system leaders must know about U.S. Department of Labor equal treatment and religion-related regulations. Retrieved from

http://www.dol.gov/cfbci/legalguidance.htm

White House. (2008, February). The quiet revolution-the president's faith-based and community initiative: A progress report. Washington, DC: Author. 